Eur. J. Clin. Chem. Clin. Biochem.

Vol. 32, 1994, pp. 843-851

(C) 1994 Walter de Gruyter \& Co.

Berlin · New York

\title{
Changes in Serum, Liver and Kidneys of Cisplatin-Treated Rats; Effects of Antioxidants
}

\author{
By E. Bogin', Mira Marom ${ }^{1}$ and Y. Levi ${ }^{2}$ \\ 1 Dept. of Biochemistry, Kimron Veterinary Institute, Beit-Dagan, Israel \\ 2 Dept. Nephrology, Hasharon Hospital, Sackler School of Medicine, Tel-Aviv University, Tel Aviv, Israel
}

(Received January 5/June 22, 1994)

Summary: Cisplatin, a nephrotoxic chemotherapeutic agent, was injected into Sprague Dawley rats, alone or together with cysteine, vitamin $\mathrm{E}$ and clonidine. The effects on erythrocyte fragility, serum composition, and kidney and liver enzymes were studied.

Cisplatin was administered as two i.p. injections $(6 \mathrm{mg} / \mathrm{kg}$ body weight) at an interval of 120 hours. The animals were sacrificed 24 hours after the second injection. Erythrocytes were prepared from blood collection with anticoagulant. Serum was prepared from clotted blood, collected without anticoagulant. Kidneys and liver were removed and homogenized, and a supernatant prepared by high speed centrifugation.

In cisplatin-treated rats, the serum activities of aspartate aminotransferase, alanine aminotransferase, lactic dehydrogenase and alkaline phosphatase were significantly decreased, whereas the activities of isocitric dehydrogenase and glutathione reductase were increased. Also, concentrations of blood urea nitrogen, creatinine, total lipids and magnesium increased while albumin and glucose decreased.

Mean osmotic fragility of erythrocytes from cisplatin-treated rats was decreased, while the haematocrit was increased.

In the liver, the only change seen was an increased activity of isocitric dehydrogenase. Much greater changes were found in the kidneys, with increased activity of glucose-6-phosphate dehydrogenase and decreased activities of aspartate and alanine aminotransferases, alkaline phosphatase, malic dehydrogenase, sorbitol dehydrogenase and $\gamma$ glutamyltransferase, as well as a decreased phosphorylation to oxidation ratio in the mitochondria, indicating reduced adenosine triphosphate production.

Administration of cysteine and vitamin $E$ together with cisplatin partially reversed the uraemia and many of the biochemical changes induced by cisplatin.

The observed intra- and extracellular biochemical changes indicate a basis for the toxic effects of cisplatin, and suggest a possible way of counteracting the toxicity by introducing protective agents such sulphydryl compounds and other antioxidants. It also appears that cells adapt to the effects of cisplatin through the induction of systems that produce NADPH, which in turn compensates the decrease of free sulphydryl groups.

\section{Introduction}

cis-Diammine dichloroplatinum (cisplatin) is an important chemotherapeutic agent used effectively in the treatment of cancers of the testes, ovary, head and neck, bladder, prostate and other organs $(1-5)$. The admin- istration of this drug however results in a significant impairment of renal function $(6-10)$.

Following the administration of cisplatin to rats, both the inulin clearance rate and the glomerular filtration rate are reduced $(6-16)$. 
Tab. 1 Enzyme catalytic concentrations in sera of control and cisplatin-treated rats

\begin{tabular}{|c|c|c|c|c|c|c|c|c|}
\hline & $\begin{array}{l}\text { Aspartate } \\
\text { amino- } \\
\text { transferase } \\
(\mathrm{U} / \mathrm{l})\end{array}$ & $\begin{array}{l}\text { Alanine } \\
\text { amino- } \\
\text { transferase } \\
(\mathrm{U} / \mathrm{l})\end{array}$ & $\begin{array}{l}\text { Isocitrate } \\
\text { dehydro- } \\
\text { genase } \\
(U / 1)\end{array}$ & $\begin{array}{l}\text { Lactate } \\
\text { dehydro- } \\
\text { genase } \\
\text { (U/1) }\end{array}$ & 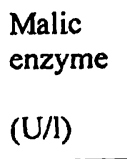 & $\begin{array}{l}\text { Glutathione } \\
\text { reductase } \\
\text { (U/l) }\end{array}$ & $\begin{array}{l}\text { Alkaline } \\
\text { phospha- } \\
\text { tase } \\
(\mathrm{U} / 1)\end{array}$ & $\begin{array}{l}\text { Malate } \\
\text { dehydro- } \\
\text { genase } \\
(\mathrm{U} / 1)\end{array}$ \\
\hline $\begin{array}{l}\text { Control } \\
\text { Cisplatin }\end{array}$ & $\begin{array}{l}169 \pm 8 \\
141 \pm 5^{*}\end{array}$ & $\begin{array}{l}51 \pm 3 \\
40 \pm 2 *\end{array}$ & $\begin{array}{c}9 \pm 1 \\
12 \pm 1^{*}\end{array}$ & $\begin{array}{l}3250 \pm 110 \\
2889 \pm 108^{*}\end{array}$ & $\begin{array}{l}50 \pm 5 \\
56 \pm 7\end{array}$ & $\begin{array}{l}52 \pm 1 \\
78 \pm 5^{*}\end{array}$ & $\begin{array}{l}383 \pm 13 \\
201 \pm 13^{*}\end{array}$ & $\begin{array}{l}1296 \pm 33 \\
1124 \pm 63\end{array}$ \\
\hline
\end{tabular}

$x \pm$ sem, $n=17-39$

* significantly different $(\mathrm{p}<0.01)$

Tab. 2 Metabolites and protein concentrations in the sera of control and cisplatin-treated rats

\begin{tabular}{|c|c|c|c|c|c|c|c|c|c|}
\hline & $\begin{array}{l}\text { Blood } \\
\text { urea } \\
\text { nitrogen } \\
(\mathrm{mmol} / \mathrm{l})\end{array}$ & $\begin{array}{l}\text { Creatinine } \\
(\mu \mathrm{mol} / \mathrm{l})\end{array}$ & $\begin{array}{l}\text { Glucose } \\
(\mathrm{mmol} / \mathrm{l})\end{array}$ & $\begin{array}{l}\text { Total- } \\
\text { proteins } \\
(\mathrm{g} / \mathrm{l})\end{array}$ & Albumin & $\begin{array}{l}\text { Globulins } \\
(\mathrm{g} / \mathrm{l})\end{array}$ & $\begin{array}{l}\text { Albumin/ } \\
\text { globulin } \\
\text { ratio }\end{array}$ & $\begin{array}{l}\text { Total } \\
\text { lipids } \\
(\mathrm{g} / \mathrm{l})\end{array}$ & $\begin{array}{l}\text { Total } \\
\text { lipids/ } \\
\text { glucose } \\
\text { ratio } \\
\text { (g/mmol) }\end{array}$ \\
\hline $\begin{array}{l}\text { Control } \\
\text { Cisplatin }\end{array}$ & $\begin{aligned} 8.2 & \pm 0.3 \\
69 & \pm 5^{*}\end{aligned}$ & $\begin{array}{c}75 \pm 6 \\
380 \pm 35^{*}\end{array}$ & $\begin{array}{l}7.6 \pm 0.2 \\
6.7 \pm 0.4^{*}\end{array}$ & $\begin{array}{l}64 \pm 1 \\
59 \pm 2\end{array}$ & $\begin{array}{l}30 \pm 1 \\
27 \pm 1^{*}\end{array}$ & $\begin{array}{l}34 \pm 1 \\
32 \pm 2\end{array}$ & $\begin{array}{l}0.88 \\
0.84\end{array}$ & $\begin{array}{l}4.9 \pm 0.2 \\
5.8 \pm 0.3^{*}\end{array}$ & $\begin{array}{l}0.64 \\
0.87\end{array}$ \\
\hline
\end{tabular}

$\mathrm{x} \pm \mathrm{sem} ; \mathrm{n}=17-39$

* significantly different $(\mathrm{p}<0.01)$

Biochemical studies with heavy metals show that they react with free sulphydryl groups. It is postulated that the nephrotoxicity caused by several heavy metals, e. g. mercury, is related to the intracellular decrease of reduced glutathione; enzymes are then inactivated because their SH-groups are not maintained in a reduced form (12). Levi et al. (15) showed that following the administration of cisplatin to rats, there was a significant decrease of SH groups per gram wet weight. This change was seen prior to the elevation of blood urea nitrogen and creatinine in the blood, suggesting that $\mathrm{SH}$ group depletion may be a primary event leading to the renal failure. The decrease of $\mathrm{SH}$ groups was due to a decrease of protein-bound $\mathrm{SH}$, with the greatest decline in the cytosolic and mitochrondrial fractions (15).

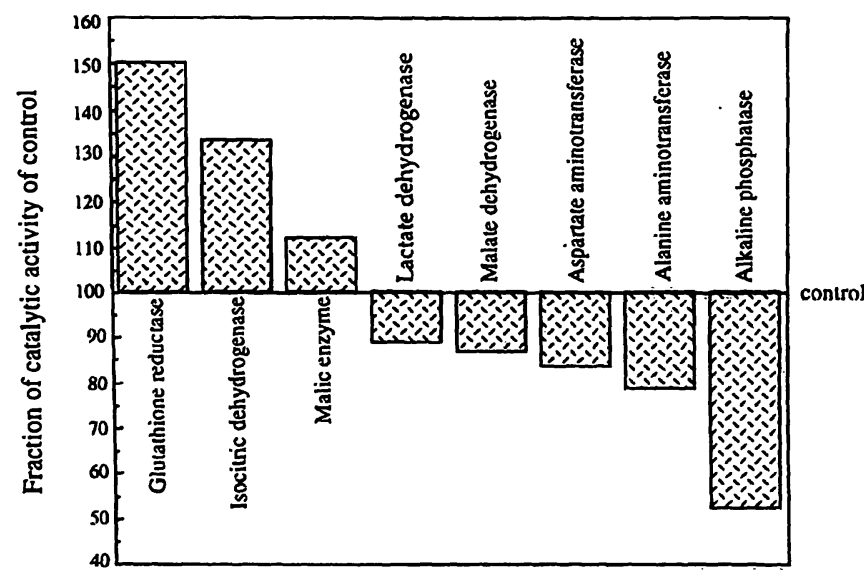

Fig. 1 Mean relative activity of enzymes in cisplatin-treated rat ${ }^{*}$ sera.
Ways of protecting SH groups and reducing the toxic effects caused by cisplatin have been reported (17-19).

The objectives of this study were to obtain information on the effects of cisplatin on various enzyme systems in the kidney, liver and blood, to relate these effects to renal failure, and to evaluate possible methods of reversing these effects by a administering compounds that protect or increase SH groups.

\section{Materials and Methods}

White male, 60 days old Sprague-Dawley rats, weighing $260 \pm 10$ grams were used. Cisplatin was injected i.p. $(6 \mathrm{mg} / \mathrm{kg}$ body weight) twice, the second injection, being given 120 hours after the first. The animals were sacrificed 24 hours after the second injection. Blood was taken from the abdominal aorta for the preparation of serum. Haematocrit and erythrocytes mean osmotic fragility were determined on heparinized blood.

Immediately after complete bleeding and death of the animal, tissues were taken, cooled to $0-4^{\circ} \mathrm{C}$ and homogenized; a cell-free supernatant was prepared for the determination of enzyme levels. Homogenization and fractionation were done according 'to a method previously described by Bogin et al. (20). Three fractions were obtained: mitochondria, microsomes and soluble fraction.

Liver and kidney tissues were homogenized in 10-fold volumes of sucrose $(0.25 \mathrm{~mol} / \mathrm{h}$, tris buffer $0.02 \mathrm{~mol} / \mathrm{l}, \mathrm{pH} 7.4)$ with a teflonglass homogenizer. Prior to homogenization, the tissues were cut into small pieces and washed three times with the homogenizing solution. The homogenate was first centrifuged at $3000 \mathrm{~g}$ for 15 minutes to remove connective tissue, cell debris, nuclei and membranes. The supernatant obtained was recentrifuged at $18.000 \mathrm{~g}$ for 30 minutes. The sediment was washed (suspension and recentrifugation in the homogenizing solution) then used as the mitochondrial fraction. The supernatant was recentrifuged at $100000 \mathrm{~g}$ for 60 minutes, and the resulting sediment used as the microsomal 
Tab. 3 Electrolyte concentrations in the sera of control and cisplatin-treated rats

\begin{tabular}{llll}
\hline Calcium & Magnesium & $\begin{array}{l}\text { Inorganic } \\
\text { phosphorus } \\
(\mathrm{mmol} / \mathrm{l})\end{array}$ \\
\hline Control & $2.84 \pm 0.05$ & $0.99 \pm 0.04$ & $3.10 \pm 0.13$ \\
Cisplatin & $2.89 \pm 0.07$ & $1.44 \pm 0.08^{*}$ & $3.33 \pm 0.19$ \\
\hline
\end{tabular}

$x \pm$ sem; $n=13-23$

* significantly different $(p<0.01)$

Tab. 4 Haematocrit and mean osmotic fragility of erythrocytes from control and cisplatin-treated rats

\begin{tabular}{lll}
\hline & Haematocrit & $\begin{array}{l}\text { Mean osmotic } \\
\text { fragility } \\
(\mathrm{g} / 1 \mathrm{NaCl})\end{array}$ \\
\hline Control & $0.417 \pm 0.007$ & $3.91 \pm 0.02$ \\
Cisplatin & $0.461 \pm 0.009^{*}$ & $3.72 \pm 0.02^{*}$ \\
\hline
\end{tabular}

$\mathrm{x} \pm \mathrm{sem} ; \mathrm{n}=8-12$

* significantly different $(p<0.01)$

fraction. This final supernatant was used for the determination of soluble enzymes.

Blood was allowed to clot, serum was obtained and the following enzymes were assayed: $L$-aspartate 2-oxoglutarate aminotransferase, EC 2.6.1.1 (21), $L$-alanine 2-oxoglutarate aminotransferase, EC 2.6.1.2 (22), L-malate : NAD oxidoreductase, EC 1.1.1.37 (23), $L$-isocitrate : NADP oxidoreductase, decarboxylating, EC 1.1.1.42 (24), $L$-lactate : NAD oxidoreductase, EC 1.1.1.27 (25), $L$-malate : NADP oxidoreductase, oxaloacetate decarboxylating, EC 1.1.1.40 (malic enzyme) (26), NAD(P)H : oxidized glutathione oxidoreductase, EC 1.6.4.2 (27), orthophosphoric monoester phosphohydrolase, EC 3.1.3.1 (28).

In the supernatant obtained from the homogenized tissues, additional enzymes were assayed: $L$-iditol : NAD 5-oxidoreductase, EC 1.1.1.14 (29), D-glucose-6-phosphate dehydrogenase, EC 1.1.1.49 (30), $L$ - $\gamma$-glutamyltransferase, EC 2.3.2.2 (31).

The enzymes, $\mathrm{Na}^{+}, \mathrm{K}^{+}$-adenosine triphosphatase, EC 3.6.1.3 $\left(\mathrm{Na}^{+}, \mathrm{K}^{+}\right.$-ATPase), and $\mathrm{Mg}$-adenosine triphosphatase, EC 3.6.1.4 $\left(\mathrm{Mg}^{2+}\right.$-ATPase), were assayed according to Post \& Sen (33) in the microsomal fractions obtained from the homogenized tissues. Mitochondrial fraction was prepared according to Johnson \& Lardy (33). Mitochondrial oxidative phosphorylation was measured with a Gilson respirometer at $30^{\circ} \mathrm{C}$ according to Smith (34). Free sulphydryl groups were measured in the supernatant according to Sedlak \& Lindsaj, (35). Protein in the various fractions was determined according to Lowry et al. (36), and the activities were expressed per $g$ protein.
The following constituents were measured in the serum: blood urca nitrogen - enzymatically (37); creatinine - colorimetrically (38); albumin - colorimetrically (39); total protein - colorimetrically (40); glu'cose - enzymatically (41); total lipids - colorimetrically (42); calcium (43) and magnesium (44) - colorimetrically; and inorganic phosphorus - colorimetrically (45). Mean osmotic fragility of the erythrocytes was measured on freshly withdrawn cells according to Parpart (46).

Internal (high and low levels) and external (DADE) quality control programs were used.

Trials to reduce the nephrotic effects of cisplatin were performed. The substances evaluated were:

1) cystcinc - a SH-containing amino acid with the potential to protect endogenous SH-groups, and, therefore to reduce the damage caused by cisplatin;

2) vitamin $E$, a substance known for its antioxidative activity and thus a potential agent for protection of SH-groups. Cysteine and vitamin $\mathrm{E}$ were used together to determine whether the combination of the two offers greater protection;

3) clonidine, a substance used as a detoxifying agent in cases of heavy metal poisoning (15). The effects of clonidine and cysteine + vitamin $E$ were studied in the absence and in the presence of cisplatin. Clonidine was given in the drinking water $(4.5 \mathrm{mg} / \mathrm{l}$ water). Cysteine $(20 \mathrm{mg} / \mathrm{kg}$ body weight) was injected together with cisplatin. Vitamin E ( $2 \mathrm{mg} / \mathrm{rat})$ was dissolved in corn oil $1: 50$, and injected s.c. together with cisplatin and cysteine.

Student's t-test was used for statistical analysis of the result

\section{Results}

There were small but significant changes in most serum enzymes studied. While isocitric dehydrogenase and glutathione reductase activities were significantly $(p<0.01)$ higher in cisplatin-treated rats, the levels of aspartate aminotransferase, alanine aminotransferase, lactic dehydrogenase and alkaline phosphatase were significantly lower. No significant differences were seen in the level of malic dehydrogenase and malic enzyme (tab. 1 and fig. 1).

The concentrations of serum proteins and metabolites in control and cisplatin-treated rats are given in table 2 . There were large significant increases in blood urea nitrogen $(406 \%)$ and creatinine $(740 \%)$ indicating renal function insufficiency. Small but significantly $(p<0.01)$ lower concentrations of blood glucose and serum albumin and higher total lipids were seen in the sera of cisplatin-treated rats.

Tab. 5 Enzyme catalytic concentratioñ in liver of control and cisplatin-treated rats

\begin{tabular}{|c|c|c|c|c|c|c|c|}
\hline . & $\begin{array}{l}\text { Aspartate } \\
\text { amino- } \\
\text { transferase } \\
\text { (U/g protein) }\end{array}$ & $\begin{array}{l}\text { Alanine } \\
\text { amino- } \\
\text { transferase } \\
\text { (U/g protein) }\end{array}$ & $\begin{array}{l}\text { Sorbitol } \\
\text { dehydro- } \\
\text { genase } \\
\text { (U/g protein) }\end{array}$ & $\begin{array}{l}\text { Malate } \\
\text { dehydro- } \\
\text { genase } \\
\text { (U/g protein) }\end{array}$ & $\begin{array}{l}\text { Lactate } \\
\text { dehydro- } \\
\text { genase } \\
\text { (U/g protein) }\end{array}$ & $\begin{array}{l}\text { Isocitrate } \\
\text { dehydro- } \\
\text { genase } \\
\text { (U/g protein) }\end{array}$ & $\begin{array}{l}\text { Alkaline } \\
\text { phosphatase } \\
\text { (U/g protein) }\end{array}$ \\
\hline $\begin{array}{l}\text { Control } \\
\text { Cisplatin }\end{array}$ & $\begin{array}{l}700 \pm 42 \\
822 \pm 83\end{array}$ & $\begin{array}{l}507 \pm 40 \\
575 \pm 69\end{array}$ & $\begin{array}{l}134 \pm 7 \\
129 \pm 7\end{array}$ & $\begin{array}{l}4208 \pm 151 \\
4010 \pm 250\end{array}$ & $\begin{array}{l}3520 \pm 569 \\
3292 \pm 381\end{array}$ & $\begin{array}{l}66 \pm 4 \\
91 \pm 9 *\end{array}$ & $\begin{array}{l}15.7 \pm 0.7 \\
16.7 \pm 1.8\end{array}$ \\
\hline
\end{tabular}

$\mathbf{x} \pm$ sem; $n=9$

* significantly different $(p<0.01)$ 
While serum magnesium was significantly $(p<0.01)$ higher $(+45 \%)$ in the cisplatin-treated rats, serum calcium and inorganic phosphorus did not change (tab. 3).

The effects of cisplatin on the erythrocytes are shown in table 4. There was a significant $(p<0.01)$ increase $(10 \%)$ in the haematocrit and a decrease $(5 \%)$ in the mean osmotic fragility.

Analysis of the soluble enzyme fraction from liver showed a significant mean increase of $38 \%(p<0.01)$ in the activity of NADP-isocitric dehydrogenase from the cisplatin-treated rats, compared with the controls. There were no significant changes in the other enzymes studied (tab. 5). Levels of soluble enzymes in the kidneys of control and cisplatin-treated rats are shown in table 6 and figure 2. A mixed pattern was seen. Aspartate aminotransferase, alanine aminotransferase, alkaline phosphatase, malic dehydrogenase, sorbitol dehydrogenase and $\gamma$-glutamyltransferase showed significantly $(p<0.01)$. lower specific activities, while glucose 6phosphate dehydrogenase was significantly higher in the cisplatin-treated rats. No significant changes were seen in the activities of isocitric dehydrogenase, lactic dehydrogenase, malic enzyme and glutathione reductase.

Measurement of mitochondrial oxidation and phosphorylation showed that the $\mathrm{P} / \mathrm{O}$ ratio was decreased in mitochondria from the kidneys of cisplatin-treated rats, i.e. these mitochondria were less efficient in the production of adenosine triphosphate. While oxidation levels were almost identical in both groups, phosphorylation was significantly $(p<0.01)$ lower in the cisplatin-treated group, decreasing the $\mathrm{P} / \mathrm{O}$ ratio by $15 \%$ (tab. 7 ).

The effects of clonidine, cysteine and vitamin $\mathrm{E}$ on changes induced by cisplatin in serum enzymes are

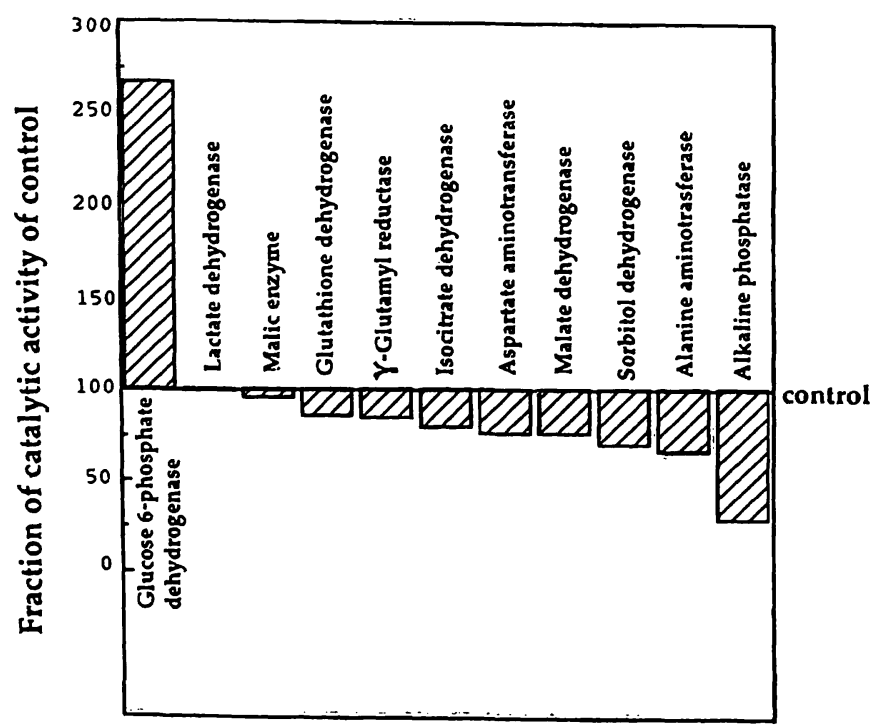

Fig. 2 Mean relative activity of enzymes in cisplatin-treated rat kidney.

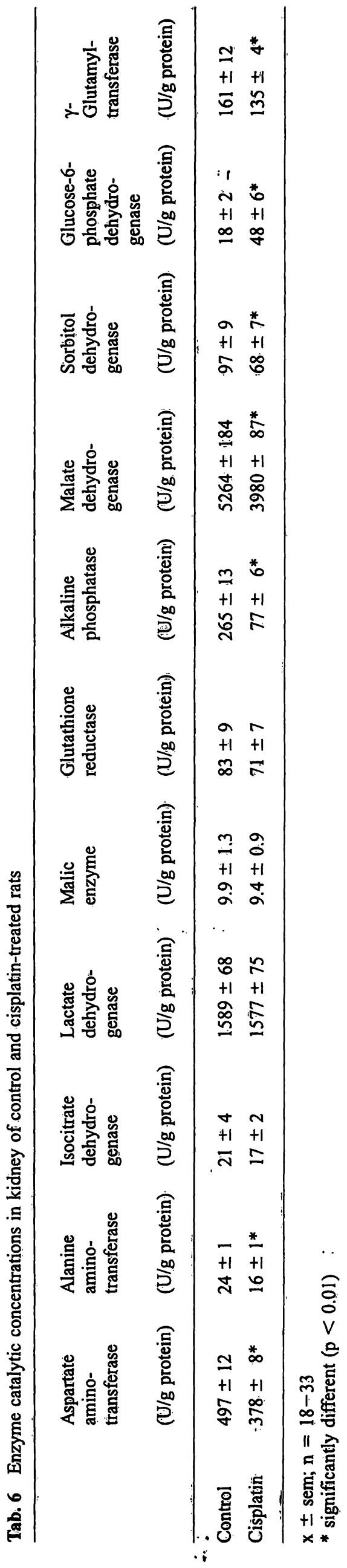

Eur. J. Clin, Chem. Clin. Biochem. / Vol. 32, 1994 / No. 11 
Tab. 7 Mitochondrial oxidation and phosphorylation from kidney of control and cisplatin-treated rats

\begin{tabular}{llll}
\hline & $\begin{array}{l}\text { Oxygen } \\
\text { consumption } \\
\left(1 / 2 \mathrm{O}_{2}, \mu \mathrm{mol} /\right. \\
\mathrm{h} \cdot \mathrm{mg} \text { protein })\end{array}$ & $\begin{array}{l}\text { Phosphorylation } \\
(\mu \mathrm{mol} /\end{array}$ & $\begin{array}{l}\mathrm{P} / \mathrm{O} \\
\text { quotient }\end{array}$ \\
\hline Control & $10.9 \pm 0.5$ & $17.8 \pm 0.7$ & \\
Cisplatin & $10.7 \pm 0.7$ & $15.1 \pm 0.6^{*}$ & $1.64 \pm 0.10$ \\
\hline
\end{tabular}

succinate was used as a substrate

* significantly different $(p<0.01)$

$\mathrm{n}=7-10$

given in table 8 . While serum aspartate aminotransferase was significantly lower after administration of cisplatin alone, the activity was not significantly different from the control when cisplatin was administered together with clonidine or together with cysteine and vitamin $\mathrm{E}$. Addition of clonidine alone did not significantly change serum aspartate aminotransferase activity. Administration of cysteine and vitamin $\mathrm{E}$ alone significantly increased serum aspartate aminotransferase activity by about $22 \%$. This stimulation however was abolished whenever cisplatin was injected together with cysteine and vitamin E. Cisplatin significantly lowered the activity of alanine aminotransferase, whereas clonidine, or cysteine together with vitamin $\mathrm{E}$, given without cisplatin did not affect serum enzyme activity. Clonidine together with cisplatin did not reverse the lowered activity of the enzyme. Cysteine and vitamin $\mathrm{E}$ given together with cisplatin led to an even greater decrease than that seen with cisplatin alone. Cisplatin caused a reduction in the activity of serum lactic dehydrogenase. While clonidine caused a significantly higher activity, cisplatin administered together with clonidine caused an even greater decrease of serum lactic dehydrogenase (tab. 8). Cyste- ine + vitamin $\mathrm{E}$ administered alone, or cisplatin together with cysteine + vitamine $E$ caused no effect on serum malic dehydrogenase activity. Clonidine on the other hand led to increased activity of malic dehydrogenase. Cisplatin administered together with cysteine and vitamin $\mathrm{E}$ caused a significant decrease of serum malic dehydrogenase.

Cisplatin, clonidine and cysteine + vitamin $\mathrm{E}$, alone or in combination, led to lower serum alkaline phosphatase activity. Clonidine, cysteine and vitamin $\mathrm{E}$ did not reverse the inhibitory effect on alkaline phosphatase by cisplatin (tab. 8).

Cisplatin and clonidine led to increased activity of glutathione reductase when added together, and the stimulation was additive. Cysteine and vitamin $\mathrm{E}$, added alone or together with cisplatin, caused little or no effect on the serum activity of glutathione reductase (tab. 8).

The effects of cisplatin, clonidine, cysteine and vitamin $E$ on kidney enzymes are shown in table 9. Alanine aminotransferase from kidney was lower following cisplatin treatment, while higher activity was seen following treatment with clonidine. Whenever both cisplatin and clonidine were administered together, the effects of each drug were neutralized by the other, so that the activity was similar to that of the untreated control group. Kidney sorbitol dehydrogenase activity was lowered by clonidine and cisplatin, and a cumulative inhibition was seen whenever both drugs were administered together. Cysteine and vitamin $\mathrm{E}$ caused a similar inhibition to that of cisplatin, but no additive effect was seen (about $29 \%)$.

A large stimulation of kidney glucose-6-phosphate dehydrogenase was seen following the administration of cisplatin. No significant effects of clonidine, cysteine

Tab. 8 Enzyme catalytic concentrations in the sera of rats following injection of cisplatin, clonidine, cysteine and vitamin $\mathrm{E}$

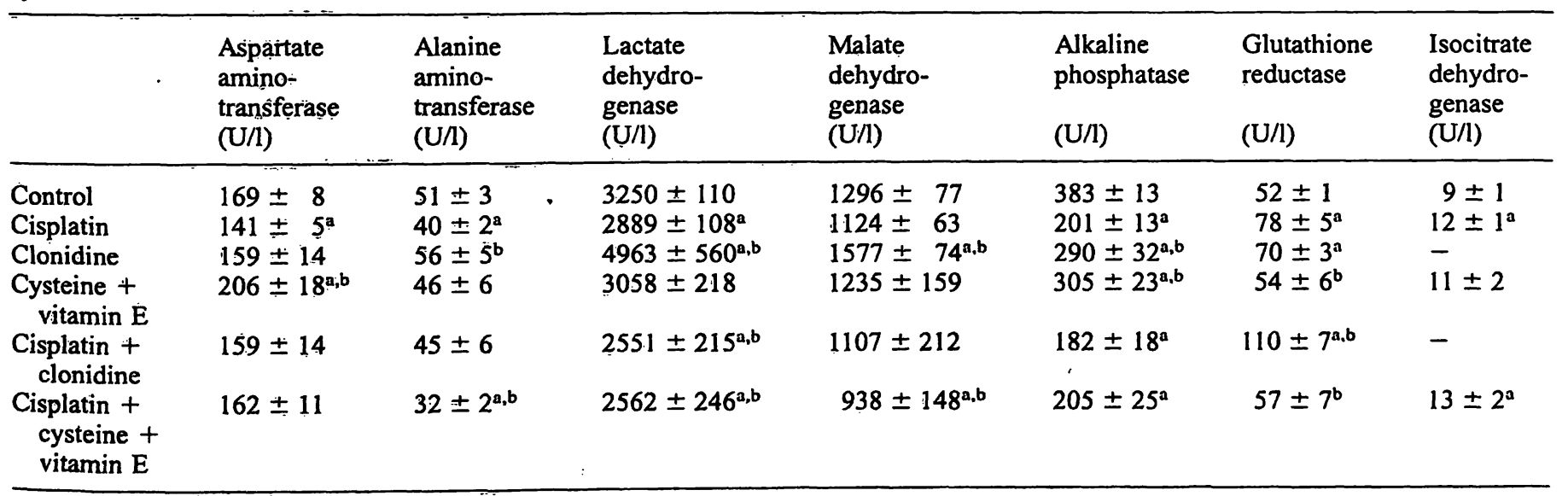

$x \pm$ sem; $n=11-36$

a - significantly different, $\mathrm{p}<0.01$, from control

$\mathrm{b}$ - significantly different, $\mathrm{p}<0.01$, from cisplatin-treated

Eur. J. Clin. Chem. Clin. Biochem. / Vol. 32, 1994 / No. 11 


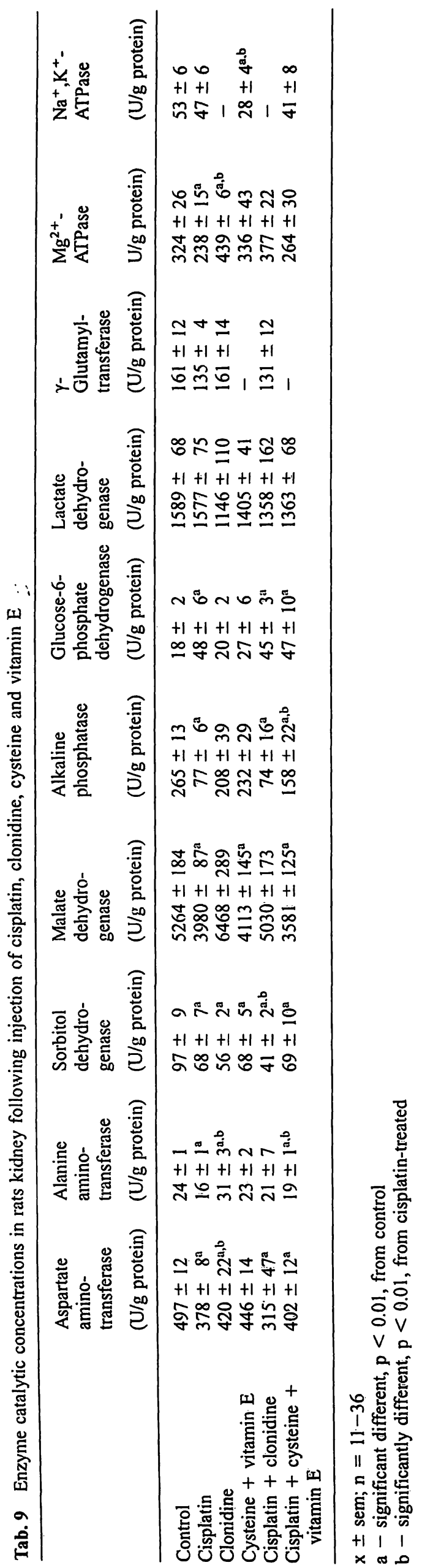

and vitamin $\mathrm{E}$, added alone or together with cisplatin, were seen (tab. 9). While kidney $\mathrm{Mg}^{2+}$-adenosine triphosphatase was significantly lower following cisplatin treatment and higher following clonidine treatment, no significant effect was seen in the activity of $\mathrm{Na}^{+}, \mathrm{K}^{+}$adenosine triphosphatase. The inhibition of kidney $\mathrm{Mg}^{2+}$-adenosine triphosphatase was reversed by the addition of clonidine (tab. 9).

The effects of cisplatin, clonidine, cysteine and vitamin $E$ on serum proteins, metabolites and electrolytes are given in table 10. Blood urea nitrogen and creatinine increased from mean values of $8.2 \pm 0.3 \mathrm{mmol} / 1$ and $75 \pm 6 \mu \mathrm{mol} / \mathrm{l}$ respectively, to $69 \pm 5 \mathrm{mmol} / \mathrm{l}$ and 380 $\pm 35 \mu \mathrm{mol} / \mathrm{l}$ respectively. While clonidine alone had little to no effect on the levels of these metabolites, it significantly increased renal failure when administered together with cisplatin. On the other hand, cysteine and vitamin $\mathrm{E}$ significantly reverse some of the effects of renal failure caused by cisplatin (tab. 10). Administration of cisplatin led to an increase in the serum concentration of $\mathrm{Mg}$ of almost $50 \%(\mathrm{p}<0.01)$. This effect was partially reversed by cysteine and vitamin $\mathrm{E}$ but not by clonidine (tab. 10).

\section{Discussion}

The present investigation focused on the biochemical aspects, kinetics and mode of action of toxic effects caused by cisplatin.

The serum enzymes, aspartate aminotransferase, alanine aminotransferase, lactic dehydrogenase and alkaline phosphatase, as well as others, are commonly elevated following cellular damage as a result of enzymes leakage from cells to the blood. The serum catalytic concentrations of these enzymes however were significantly lower 120 hours post cisplatin administration in the treated animals, suggesting an inhibitory effect. Lower enzyme levels may be due to either lower release from the tissues to the serum, or decreased production of active enzymes and consequently lower activity in the serum.

It has been postulated that the nephrotoxic mode of action of the drug cisplatin is similar to that of other heavy metals, and is related to the decrease in the intracellular concentrations of glutathione and protein-bound SHgroups, which are required for normal cellular function ". $(1-5,8-11,14,15)$.

The possibility that cisplatin itself is the inhibitory agent of the enzymatic reaction was excluded by the fact that in vitro addition of the drug to the reaction media did : not affect the reaction rates (unpublished observations). 
Tab. 10 Protein, metabolite and electrolyte concentrations in the sera of rats following injection of cisplatin, clonidine, cysteine and vitamin $\mathrm{E}$

\begin{tabular}{|c|c|c|c|c|c|c|c|c|c|}
\hline & $\begin{array}{l}\text { Blood urea } \\
\text { nitrogen } \\
(\mathrm{mmol} / \mathrm{l})\end{array}$ & $\begin{array}{l}\text { Creatinine } \\
(\mu \mathrm{mol} / 1)\end{array}$ & $\begin{array}{l}\text { Total } \\
\text { proteins } \\
(\mathrm{g} / \mathrm{l})\end{array}$ & $\begin{array}{l}\text { Albumin } \\
(\mathrm{g} / 1)\end{array}$ & $\begin{array}{l}\text { Total } \\
\text { lipids } \\
\text { (mmoln) }\end{array}$ & $\begin{array}{l}\text { Glucose } \\
\text { (mmol/l) }\end{array}$ & $\begin{array}{l}\mathrm{Ca} \\
(\mathrm{mmol} / \mathrm{l})\end{array}$ & $\begin{array}{l}\mathrm{Mg} \\
(\mathrm{mmol} / \mathrm{l})\end{array}$ & $\begin{array}{l}\mathrm{P} \\
(\mathrm{mmol} / \mathrm{l})\end{array}$ \\
\hline Control & $8.2 \pm 0.3$ & $75 \pm 6$ & $64 \pm 1$ & $30 \pm 0.4$ & $4.9 \pm 0.2$ & $7.6 \pm 0.2$ & $2.84 \pm 0.05$ & $0.99 \pm 0.04$ & $3.10 \pm 0.13$ \\
\hline Cisplatin & $69.0 \pm 5.0^{a}$ & $380 \pm 35^{a}$ & $59 \pm 2$ & $27 \pm 0.6^{a}$ & $5.8 \pm 0.3^{a}$ & $6.7 \pm 0.4^{a}$ & $2.89 \pm 0.07$ & $1.44 \pm 0.08^{a}$ & $3.33 \pm 0.19$ \\
\hline Clonidine & $8.5 \pm 0.7$ & $57 \pm 4$ & $67 \pm 2^{b}$ & $35 \pm 1.5^{b}$ & $4.9 \pm 0.2$ & $6.9 \pm 0.3$ & $2.82 \pm 0.10$ & $0.99 \pm 0.04$ & $2.87 \pm 0.13$ \\
\hline $\begin{array}{l}\text { Cysteine + } \\
\text { vitamin } \mathrm{E}\end{array}$ & $7.0 \pm 0.7$ & $80 \pm 6$ & $65 \pm 2$ & $30 \pm 0.8$ & $4.8 \pm 0.4$ & $6.8 \pm 0.4$ & $2.79 \pm 0.10$ & $1.09 \pm 0.07$ & $3.52 \pm 0.36$ \\
\hline $\begin{array}{c}\text { Cisplatin + } \\
\text { Clonidine }\end{array}$ & $83 \pm 5^{a . b}$ & $610 \pm 80^{a, b}$ & $60 \pm 2$ & $27 \pm 1.5$ & $5.6 \pm 0.3$ & $6.6 \pm 0.3^{a}$ & $2.71 \pm 0.24$ & $1.56 \pm 0.08^{a}$ & $3.33 \pm 1.03$ \\
\hline $\begin{array}{c}\text { Cisplatin + } \\
\text { cysteine }+ \\
\text { vitamin E }\end{array}$ & $50 \pm 9^{a}$ & $168 \pm 27^{a . b}$ & $60 \pm 2$ & $29 \pm 0.6$ & $5.2 \pm 0.5$ & $6.2 \pm 0.4^{\mathrm{a}}$ & $2.74 \pm 0.08$ & $1.28 \pm 0.05^{\mathrm{a}}$ & $2.84 \pm 0.26$ \\
\hline
\end{tabular}

$x \pm$ sem; $n=11-36$

$a-$ significantly different, $p<0.01$, from control

$b$ - significantly different, $p<0.01$, from cisplatin-treated

The lower activities of enzymes in the serum parallelled the intracellular pattern. Administration of substances containing sulphydryl groups, or with antioxidant properties, together with cisplatin, significantly reversed the inhibitory effects caused by cisplatin alone, supporting the hypothesis that the cisplatin toxicity is associated with the reduction of free sulphydryl groups.

Addition of both cysteine and vitamin E significantly reversed the toxic effects caused by cisplatin. The degree of uraemia was lowered and the magnitude of the changes in the serum analytes, including glutathione reductase, were smaller. These findings may suggest that some of the toxic effects caused by cisplatin may be reduced by using cysteine and vitamin $\mathrm{E}$. This, however, needs to be further studied, in case the chemotherapeutic effect of cisplatin is also reduced.

In response to the lower SH concentrations caused by cisplatin, we observed:

(a) increased activities of the serum enzymes, NADPisocitric dehydrogenase and glutathione reductase,

(b) significant increases in liver isocitric dehydrogenase and kidney glucose 6-phosphate dehydrogenase, all of these enzymes being associated with NADPH generation and maintenance of reduced sulphydryl groups.

Tab. 11 Effect of time of second cisplạtịn injection on renal function

\begin{tabular}{rcr}
\hline $\begin{array}{l}\text { Time } \\
\text { (h) }\end{array}$ & $\begin{array}{l}\text { Blood urea nitrogen } \\
(\mathrm{mmol} / \mathrm{l})\end{array}$ & \multicolumn{1}{c}{$\begin{array}{l}\text { Creatinine } \\
(\mu \mathrm{mol} / \mathrm{l})\end{array}$} \\
\hline 0 & $9 \pm 1$ & $80 \pm 9$ \\
72 & $75 \pm 1.4$ & $398 \pm 115$ \\
96 & $62 \pm 9$ & $362 \pm 62$ \\
120 & $70 \pm 9$ & $354 \pm 71$ \\
\hline
\end{tabular}

$\mathrm{x} \pm \mathrm{SD} ; \mathrm{n}=11-36$
By constantly preventing oxidative processes, sulphydryl groups also have an important role in the maintenance of cellular membrane integrity. The lowering of the SH level caused by cisplatin could be a contributing factor to the observed decrease in mean osmotic fragility.

The effect of cisplatin was much greater on the kidney than the liver. While only one enzyme was found to change in the liver (NADP isocitric dehydrogenase, increasing by $38 \%$ ), seven kidney enzymes showed a change in activity (six reduced and one increased). Renal failure in rats treated with cisplatin could be a result of the lower enzymatic activities in the kidney, as well as the less efficient oxidative phosphorylation and adenosine triphosphate production of the mitochondria. The enzyme shown to be most inhibited both in the serum and kidney is alkaline phosphatase. The reason for its great sensitivity is not clear. Through its role as a membrane enzyme involved in transmembranal transport (among other functions), alkaline phosphatase may be particularly involved in the renal failure and development of uraemia.

Following the administration of cisplatin, uraemia developed and the activity of serum enzymes was significantly decreased (tab. 11). This was largely reversed by supplementation with cysteine and vitamin $\mathrm{E}$ (but not clonidine), once again indicating on the possible potential of these compounds to reverse the toxic effects caused by cisplatin. Similar patterns, although of lesser magnitude, were also seen with other kidney enzymes (alanine aminotransferase and aspartate aminotransferase). It is, however, necessary to evaluate the efficiency of these compounds when given after cisplatin treatment rather than during treatment, since the combined supplementation of cisplatin together with vitamin $E$ and cysteine may reduce the chemotherapeutic efficiency of cis-

Eur. J. Clin. Chem. Clin. Biochem. / Vol. 32, 1.994 / No. 11 
platin. The availability of appropriate biochemical indicators of the degree of nephrotoxicity will enable further study of these aspects of the problem.

Of interest is the effect of clonidine, which did not reverse the toxic effects of cisplatin, but in most cases even increased the toxicity of the chemotherapeutic substance.

The increased blood cell volume seen in the cisplatintreated rats could be related to the renal failure, leading to loss of body fluids and haemoconcentration and therefore an increased haematocrit. The fact that total protein was reduced could be explained by the loss of protein in the urine. Significant proteinuria was seen in the cisplatin-treated rats, confirming the results of other others (9). This is further supported by the lower serum albumin levels in the treated rats.

Evaluation of the toxicological effects of cisplatin leads to the following conclusions.

\section{References}

1. Einhorn, L. H. \& Donohue, J. (1977) cis-Diamminedichloroplatinum, vinblastine and bleomycin combination chemotherapy in disseminated testicular cancer. Ann. Intern. Med. 87, 293-298.

2. Rozencweig, M., Von-Hoff, D. D., Slavik, M. \& Muggia, F. M. (1977) Cis-diamminedichloroplatinum (II). A new anticancer drug. Ann. Intern. Med. 86, 803-812.

3. Lippman, A. J., Helson, C. \& Krakoff, I. H. (1973) Clinical trials of Cis-diamminedichloroplatinum II. Cancer Chemother. Rep. 57, 191-200.

4. Gottlieb, J. A. \& Drewinko, B. (1975) Review of the current clinical status of platinum coordination complexes in cancer chemotherapy. Cancer Chemother. Rep. 59, 621-628.

5. Malseen, R. T. (1982) Pharmacology: Drug Therapy and Nursing Considerations. J. B. Lippincott Comp. USA.

6. Wittes, R. G., Dvitkovic, E., Shaj, J., Gerold, F. \& Strong, E. W. (1977) Cis-dichlorodiammineplatinum (II) in the treatment of epidermoid carcinoma of the head and neck. Cancer Treat. Rep. 61, 359-366.

7. Dentino, M., Luft, F. C., Yum, M. N., William, S. D. \& Einhorn, L. H. (1978) Long term effect of cis-diamminedichlorideplatinum (CDD) on renal function and structure in man. Cancer 41, 1274-1281.

8. Ballantyne, B., Marrs, T. \& Turner, P. (1993) General and Applied Toxicology. M. Stockton Press.

9. Haschek, W. M. \& Rousseaux, C. G. (1991) Handbook of Toxicologic Pathology. Academic Press. San Diego, New York, Boston, London, Sydney, Tokyo, Toronto.

10. Litterst, C. L. \& Weiss, R. B. (1987) Clinical and experimental nephrotoxicity of cancer chemotherapeutic agents. In: Nephrotoxicity in the Experimental and Clinical Situation (Bach, P. H. \& Lock, E. A., eds.) Vol. 2, Martinus Nijhof. Lancaster.

11. Borch, R. F. \& Markman, M. (1989) Biochemical modulation of cisplatin toxicity. Pharmacol. Ther. 41, 371-380.

12. Cafruny, E. J., Farah, A. \& DiStefano, H. S. (1955) Effect of the mercurial diuretic mersalyl on protein-bound sulfhydryl groups in cytoplasm of rat kidney cells. J. Pharmacol. Exp. Ther. 115, 390-401.

13. Chopra, S., Kaufman, J. S., Jones, T. W., Hong, W. K., Gehr, M. K., Hamburger, R. J., Flamenbaum, W. \& Trump, B. J. a) Blood and tissue analysis confirmed that the kidney is very sensitive to cisplatin toxicity, and more sensitive than the liver.

b) An intracellular compensatory effect was observed following cisplatin administration. This compensatory process neutralized the effects off cisplatin, by increasing the activities of enzymes associated with NADPH production and the maintenance of sulphydryl groups in their reduced state.

c) The toxic effects and degree of renal failure were decreased by cysteine and vitamin $E$, which also partially neutralized the various changes in enzyme activity, etc. caused by cisplatin.

d) Renal failures caused by the administration of cisplatin is the result of reduced activities of several enzymes that play a role in renal function, as well as reduced adenosine triphosphate production due to uncoupling of the mitochondrial oxidative phosphorylation.

(1982) Cis-diammine dichloroplatinum induced acute renal failure in the rat. Kidney Int. 21, 54-61.

14. Safitstein, R., Milter, P., Dickman, S., Lyman, N. \& Shapiro, C. (1981) Cisplatin nephrotoxicity in rats: Defect in papillary hypertonicity. Am. J. Physiol. 241, F175-F185.

15. Levi, J., Jacobs, C., Kalman, S., McTighe, M. \& Weinder, M. W. (1980) Mechanism of cis-platinum nephrotoxicity. I. Effect on SH groups in rat kidney. J. Pharmacol. Exp. Ther. 213, $545-550$.

16. Weiner, W. M. \& Jaçobs, C. (1983) Mechanism of cis-platin nephrotoxicity. Federation Proc. 42, 2974-2978.

17. Boogaard, P. J., Lempers, E. L. M., Muller, G. J. \& Meerman, J. H. N. (1991) U-Methylthiobenzoic acid reduces cisplatin nephrotoxicity in rats without compromising anti-tumour activity. Biochem. Pharmacol. 41, 369-375.

18. Baldew, G. S., Hamer, C. J. A., Van den Los, G., Vermeulen, N. P. E., de Goeji, J. J. M: \& McVie, J. G. (1989) Selenium induced protection against cisplatin (II). Nephrotoxicity in mice and rats. Cancer Res. 49, 3020-3023.

19. Litterst, C. L. (1981) Alterations in the toxicity of cisplatin and in tissue localization of platinum as a function of $\mathrm{NaCl}$ concentration in the vehicle of administration. Toxicol. Appl. Pharmacol. 61, 99-108.

20. Bogin, E. \& Israeli, B. (1976) Enzyme profile of heart and skeletal muscle, liver and lungs of roosters and geese. $\mathrm{Zbl}$. Vet. Med. 23, 152-157.

21. Bergmeyer, H. U., Herder, M. \& Rej, R. (1986) Method for the measurement of catalytic concentration of enzymes. IFCC method for aspartate aminotransferase. J. Clin. Chem. Clin. Biochem. 24, 497-510.

22. Bergmeyer, H. U., Herder, M. \& Rej, R. (1986) Method for the measurement of catalytic concentration of enzymes. IFCC method for alanine aminotransferase. J. Clin. Chem. Clin. Biochem. 24, 481-495.

23. Bergmeyer, H. U. \& Bernt, E. (197.4) Malate dehydrogenase. In: Methods of Enzymatic Analysis (Bergmeyer, H. U., ed.) Vol. 2, English edition. pp. 613-617. Verlag Chemie Weinheim. Academic Press Inc. New York, San Francisço, London.

24. Bernt, E. \& Bergmeyer, H. U. (1974) Isocitrate dehydrogenase. In: Methods of Enzymatic Aṇalysis (Bergmeyer, H. U., ed.) 
2nd English edition. pp. 624-627. Vcrlag Chemie Weinheim, Acad. Press. Inc. New York, San Francisco and London.

25. Bergmeyer, H. U. \& Bernt, E. (1974) Lactate dehydrogenase. In: Methods of Enzymatic Analysis (Bergmeyer, H. U., ed.) 2nd English edition. Vol. 2, pp. 574-579. Verlag Chemie Weinheim. Academic Prcss Inc. New York, San Francisco and London.

26. Hsu, R. Y. \& Lardy, H. A. (1969) Malic enzyme. In: Methods in Enzymology (Colowick, S. P. \& Kaplan, N. O., eds.) Vol. 23, pp. 230-235. Academic Press, New York and London.

27. Bergmeyer, H. U. (1974) Glutathione reductase. In: Methods of Enzymatic Analysis. Vol. 1, pp. 465-466. Verlag Chemie International, Deerfield Beach, Florida.

28. McComb, R. B. \& Bowers, G. N. (1972) Study of optimum buffer condition for measurement of alkaline phosphatase activity in human serum. Clin. Chem. 18, 97-104.

29. Gerlach, U. \& Hiby, W. (1974) L-Iditol dehydrogenase. In: Methods of Enzymatic Analysis (Bergmeyer, H. U., ed.) Vol. 1, pp. 569-573. Verlag Chemie Weinheim, Academic Press, New York, San Francisco and London.

30. Lohr, G. W. \& Waller, H. D. (1974) Glucose-6-phosphate dehydrogenase. In: Methods of Enzymatic Analysis (Bergmeyer, H. U., ed.) 2nd English edition. Vol. 2, pp. 636-643. Verlag Chemie Weinheim, Academic Press Inc., New York, San Francisco, London.

31. Szasz, G. (1974) Reaction rate method for gamma glutamyltransferase activity in serum. Clin. Chem. 22, 2051-2055.

32. Post, R. L. \& Sen, A. K. (1967) Sodium and potassium stimulated adenosine triphosphatase. In: Methods in Enzymology (Eastbroo, R. E. \& Pullman, M. E., eds.) Vol. 10, pp. 762771. Academic Press. New York, San Francisco, London.

33. Johnson, D. \& Lardy, H. (1967) Isolation of liver or kidney mitochondria. In: Methods in Enzymology' (Eastbrook, R. W. \& Pullman, M. E., eds.) Vol. 10, pp. 94-103. Academic Press, New York, San Francisco, London.

34. Smith, A. L. (1967) Preparation, properties and conditions for assay of mitochondria. In: Methods in Enzymology (Eastbrook, R. W. \& Pullman, M. E., eds.) Vol. 10, pp. 81-93. Academic Press, New York, San Francisco, London.
35. Sedlak, J. \& Lindsay, R. (1968) Estimation of total proteinbound and non-protein sulfhydryl group in tissue with Ellman's reagent. Anal. Biochem. 25, 192-195.

36. Bailey, S. L. (1962) Techniques in Protein Chemistry. Elsevier Publishing Comp. Amsterdam, London, New York.

37. Talk, H. \& Shubert, G. E. (1965) Enzymatische Harnstoffbestimmung im Blut und Serum. Klin. Wochenschr. 43, 174-175.

38. Fabiny, D. L. \& Ertingshausen, G. (1971) Automated reaction rate method for the determination of serum creatinine. Clin. Chem. 17, 696-700.

39. Doumas, B. T., Watson, W. A. \& Biggs, H. G. (1971) Albumin standards and the measurement of serum albumin with bromocresolgreen. Clin. Chim. Acta 31, 87-96.

40. Gornall, A. G., Bardawill, C. J. \& David, M. M. (1949) Determination of serum proteins by means of biuret reactions. $\mathrm{J}$. Biol. Chem. 17, 751-766.

41. Bonder, R. J. L. \& Mead, D. C. (1974) Evaluation of glucose6-phosphate dehydrogenase from Leuconostic mesenteroides in the hexokinase method for determining glucose in serum. Clin. Chem. 20, 586-590.

42. Frings, C. S., Fendly, T. W., Dunn, R. T. \& Queen, C. A. (1972) Improved determination of total serum lipids by the sulphophosphovanillin reaction. Clin. Chem. 18, 673-674.

43. Bauer, P. D. (1981) Affinity and stoichometry of calcium binding of arsenazo. Anal. Biochem. 110, 61-72.

44. Khayam-Bashi, H., Liv, T. Z. \& Walter, V. (1977) Measurement of serum magnesium with centrifugal analyzer. Clin. Chem. 23, 289-291.

45. Daly, J. A. \& Ertingshausen, G. (1972) Direct method for determining inorganic phosphate in serum with the Centrifichem. Clin. Chem. 18, 263-265.

46. Parpart, A. K., Lorenz, R. B. \& Parpart, E. (1947) The osmotic resistance of human red cells. J. Clin. Invest. 26, 636-640.

Prof. Dr. E. Bogin

Dept. Biochemistry

Kimron Veterinary Institute

Tel-Aviv University

P. O. Box 12

Beit Dagan

50250 Israel 
